\title{
6. Sex Workers and Police in Port Moresby (1994-1998): Research and Intervention
}

\section{CAROL JENKINS}

The structure of the sex trade in Papua New Guinea and much of the rest of the Pacific differs from that in Asia in several important ways. For the most part, women are free-lancing. They are not under contract to a brothel or other manager, and can take their clients where they find them without need to share their earnings with others. Throughout the Pacific, ports, beaches, malls, night clubs, guesthouses, hotels and residences are common sites at which commercial sex is negotiated and/or carried out. In cities with crowded poor housing areas, sex is sold or exchanged for goods within those neighbourhoods and in local parks or open fields as well. At rural economic enclaves, such as logging camps, fisheries depots, mines and plantations, sex workers (SWs) are also present, particularly on pay days. Increasingly, urban sex work is becoming cell phone-coordinated in a number of cities of the Pacific region. In Suva, Chinese businessmen have instituted a more organised and controlled sex trade in brothels with imported Chinese women brought in to serve Asian sailors and fishermen. Anecdotal evidence suggests that Asian businessmen have been managing a certain portion of the sex trade in Port Moresby for a number of years.

In all countries, the organisation of the sex trade is very sensitive to pressures applied by legal forces. If sex workers are frequently rounded up and arrested, the trade morphs, moves elsewhere, goes underground and hides. Wherever sex work is illegal, the police are significant regulators of the sex trade and as numerous studies have shown, can become extremely abusive of their power (Blankenship and Koester 2002; Phal 2002; see also in this volume Hammar; Stewart; Fletcher and Bonapa). That is not inevitable, however, and in New York City, where an internal monitoring unit now tracks complaints of police abusiveness, a recent study showed that street sex workers are harassed and arrested, but not physically assaulted or raped (SWP 2003), as in Cambodia, Bangladesh and elsewhere (Jenkins et al. 2005; Government of Bangladesh 
2000). Even in Ethiopia and Eritrea, NGO workers and fishermen clients of sex workers report that some police are willing to help sex workers by arresting men who refuse to pay them, or even intervene if clients refuse to use condoms. With enough good advocacy directed at those who abuse sex workers and an emphasis on sex workers' human rights, there is a good chance of improving their situation (Jenkins 2000).

Violence against sex workers, including rape, appears to form a pattern based on revilement of the public woman and is worse where women in general have little public power. In numerous Pacific nations, rape and violence against women is widespread though, as yet, not well documented. Many Melanesian societies, in particular, have the classic characteristics of rape-prone societies, that is, high levels of general violence, male dominance and the silencing of female sexuality (Sanday 1986; Buchanan et al. 1999; Goldberg and Unité 2005, 88; Pelletier 2002; see also Eves this volume; Hammar this volume), particularly after the imposition of Western Christian values. Traditionally, rape has been used to punish women for any number of transgressions in some Melanesian societies, and in contemporary life, gang rape has become particularly common as men use it to steal what they cannot (or will not) buy or to discipline women who challenge the existing gender power dynamics or simply to pay back the prior rape of their own group's women. ${ }^{1}$ Gang rape appears to have unique social dynamics, different from any associated with intimate partner violence or other individually perpetrated rape, in that it can become a locally 'acceptable' expression of male bonding and homoeroticism without appearing to be connected with homosexuality at all (Jenkins 1996). In addition, where rape is common and HIV levels high, the contribution of rape to the spread of HIV is well documented (Donovan 2002; Smith 2003).

This chapter is based largely on data collected by the Papua New Guinea Institute of Medical Research from 1995 to 1998 as part of a project called the Transex Project (for transport workers and sex workers) funded by AusAID ${ }^{2}$. Additional funding was secured for one year from UNAIDS specifically to reduce the frequency of gang rape of sex workers by police in Port Moresby. At that time, inquiries in Lae and Goroka did not suggest a similar problem in those locations. However, preliminary work in Port Moresby identified gang rape, called lainaps or other terms, as a major problem faced by sex workers.

\footnotetext{
1 1Editors' note: The author is using the term 'gang' to mean any group of men, without some of the connotations of 'gang' as a highly organised body.

2 Editors' note: as indicated in the introduction to this collection, Carol Jenkins' chapter is best read in conjunction with the following chapter by McLeod and Macintyre, which puts the findings here in the light of more recent developments.
} 


\section{Methods}

The work began in 1994 with an ethnographic study of the sex trade, including a total of 116 written observational sessions, 36 key informant interviews (mostly with owners or managers of houses in which rooms are rented for sex or men and women who act as boskru, a kind of protector to sex workers), and in-depth private interviews with 85 self-defined female SWs and 116 clients in six locations (Lae, Goroka, Highlands Highway, Ramu Sugar and Port Moresby).

From the observations and interviews with sex workers it was learned that police were their main source of harassment. Sex workers were rarely physically abused by venue managers, even though they were sometimes sent away from venues such as hotels or restaurants. Despite the fact that policemen were often paying clients of SWs, they also frequently beat and sexually abused these women. Out of 85 interviews, 12 discussed problems with the police and half of those stated they had been forced to give sex to the police in order to avoid being jailed. Usually, they were picked up for drunken behaviour, often in cars which were driven recklessly. Some were picked up for vagrancy and others had been harassed for selling betel nut since a ban was put in place against the sale of betel nut outside of designated markets within Port Moresby. One woman tried to lodge a police report about being raped but, because she was known as a SW, the police refused to help her. Several stated that women known as tu-kina and taken in by the police were at high risk of being raped by a large number of policemen. They stated that the policemen called over their car radios to different precincts asking if other officers wish to join in. When asked how their lives as SWs might be improved, one common response was to stop the police from beating and sexually abusing them. While not as frequent, the women also mentioned that security men working at various buildings at night also took advantage of them, and engineered lainaps in exchange for allowing them to sleep or rest at their post. This information led to the collection of seven in-depth taped interviews with police by trained ex-policemen, and the addition of eight interviews with security men. These interviews corroborated the women's stories. The following are excerpts from two such interviews with single policemen in their mid-20s. The various situations in which police can coerce women into having sex with them alone or with a group of policemen are described. It seems, in the case of the second interview below, that the man is making an argument based on the types of women, or types of circumstance in which they acquire these women. 


\section{Interview 1:}

Yes, as best friends we do share some girls that they bring into the barracks. Well, girls like the ones that we pick up from the street side, outside the clubs while patrolling or other girls that policemen know very well of as regular providers to policemen. I mean those girls that we know very well and provide sex to us. We don't pay them, why do we have to pay for the stinking kan. Free Sex. No, she won't refuse. If she does, she will be in trouble. We always bash them up and so they know this very well. If such a girl is brought to the barracks, then that's for everybody.

Just last week I brought one. We picked her up next to PNGBC in town and it was time for me to sign off duty so I asked the driver to drop both of us off at Gordon Barracks and he did. I don't know but she told me that she was coming up from the wharf. She then told me that she was on her way to sleep and I forced her to jump on so. She got on and we went straight to the barracks. I think it was about $11.30 \mathrm{pm}$ because I signed off duty at $11.00 \mathrm{pm}$. Anyway, some clever guys must have seen us going into my room, and not long after that I heard a knock on the door. As soon as I opened the door, I saw one of my friends standing right in the doorway. He then asked me, can you transfer her to my room as soon as you finish with her?

So I fucked her only twice and I sent her into another room. No, it did not take long. I think about 10 minutes only. No, she smelled very bad, why should I keep her there? She smelled of sweat, like she did not wash. I think she must have smelt of beer too. Good girls don't smell like that. She did not even sleep on the bed, she slept on the floor and I screwed her. Just normal position. Yes, I know, I have to use condoms. I used it twice because that was the only last one I have.

Yes that's right, she refused to go to the next room but I told her to fuck off from my room. She begged me to stay and I forced her to go outside. As soon as I closed the doors, I went off to sleep. I don't know what happened to the girl. I think they were watching so they just pulled her into one of the rooms.

\section{Interview 2:}

Bro, I think you have been in the system yourself and you know it. So I would tell you that I don't normally go out looking for girls for sex in night clubs or discos. The public is against us and I don't want to be beaten up in the night clubs. You mean pay for sex? That is quite new 
to me. I did not fuck a girl who demanded cash or money from me yet. I fuck for nothing, why pay? I'm telling you the facts. Policemen fuck like nobody's business. How many times we bring girls into this single barracks, they never demand for money. That's correct, we do group sex too. Well, you know the system yourself, brother boy!

Policeman can fuck at anytime, any place. Brother you listen, I will tell you. I get girls or women, no matter single or married so long as she agrees to fuck when she comes to the police station to lay complaints such as she was beaten by the husband, brother, father or their money was stolen or any complaints. Brother, any time, day or night, but most of the time is night. You just pay a visit to any of police stations in town and see. You will see that people are always there, some arguing, screaming and shouting at each other and others laying complaints at the duty counter. You know, any girl taken out by a police car to attend her complaint and to look for the suspect, the accused that she wants to be arrested, she has to be asked for a fuck. If she agrees, that's it, fuck her. No, we don't pay her too. If she smokes, we offer her cigarette or buai [betel net].

Yes, sometimes but sometimes not. Group sex does not apply in this case. Because we don't want to create trouble such as getting reported for rape or group sex and so on. As I've said you know the system. If she is forced against her will to have sex with all the policemen who are in the car then we expect rape charge next day. In this case the person who is in charge of her complaint or report only fucks. You sometimes see in the media, newspapers about policemen raping a woman, because they don't comply with what I've just said.

Also there are certain girls that we know of. They are regular faces to policemen and we fuck them whenever we meet them and that is when group sex comes in. Sometimes we see them and ignore them, we got tired of fucking them. We call them public toilets. When ever we feel like fucking, we go looking for them. As soon we spot them, we tell them to climb into the car or van. If they refuse, we use force to get them in. We always bash them up so they know our ways. We pick them up any place, on the streets, outside the clubs, any place. They seem to be everywhere. Yes, sometimes we bash them up and order them to get into the car. Well, where will they go and report or lay complaints? Every policeman and policewoman in town knows them very well. They are known as 'public toilets'. As soon as we see them coming to the police station and say that they have been raped, beaten or anything, we chase 
them away. Nowadays, they don't come to the police station because they know very well that their reports won't be heard. Yes, that's right, as we ask them to hop in, they just hop in because now they are frightened.

Here are some of the places where group sex takes place.

1: At the back of police station.

2: Police Van.

3: Dark and open fields around the city.

4: Police barracks.

Bro, I won't tell you how many times I get myself involved in group sex because I don't count it. It just happens at any time of the week or month. Well, as I've said any time once a week, twice a week. It is hard to count. You know, if any policeman brings a woman to the barracks, that's for the group. I mean apart from the regular girl friends. I don't know, it could be 8, 9, 10 men or more. I only go once and go to sleep. I don't know how many men go after me and go before me to fuck her. Well, because after fucking her, I don't stand there and count. Yes, now I'm using condoms. I use Protector condoms, the ones with the brown plastic cover. Because I'm frightened of getting AIDS. This disease is terrible and I don't want to be one of the victims of it.

No, I don't use it with my regular girl friend because we trust each other. It is true that when we get girls from the street, I sometimes don't fuck them when I don't have condoms.

In order to gain an estimate of how frequently these lainaps by police or security men took place, quantitative surveys were needed. After approaching the Police Commissioner with the problem and seeking his support for developing a special HIV intervention for the police, the funding was secured from UNAIDS and baseline surveys of policemen and policewomen were conducted as the training for peer educators begun. This was followed up nine months later, just before the UNAIDS funding ended, with a second survey of policemen. Baseline surveys were also carried out among security men from four major security firms. Work continued with police after this funding ran out but at a reduced level. An additional survey of policemen and security men took place at the end of the entire Transex Project in 1998. All questionnaires were written in Pidgin and pre-tested. Interviewers, male staff of the Transex Project, were trained and all data double-entered at the PNGIMR headquarters in Goroka. Interviewers for each of the follow-up surveys of policemen and security men were male staffers who had been working with other male groups, such as sailors, in order to reduce self-reporting bias. 
Our sampling for the surveys aimed at geographical representativeness, but these cannot be considered probability samples. No statistical analyses were attempted except simple Mantel-Haentzel chi square comparisons using SAS 6.0 .

\section{Intervention}

The intervention consisted, first, of sensitising high-level police officials to the risks revealed in the small qualitative studies and seeking their support for a targeted behaviour change program for the police. While there were no official statistics on HIV among the police available at the time, officials and others knew several policemen who had already died of AIDS. One HIVpositive policewoman was publicly vocal about the issues and repeatedly collaborated with the program. The police commissioner was very cooperative and wrote a letter to all precincts in the country instructing them to cooperate with this effort. Unfortunately, no funding was ever made available to cover police in any other section of the country, except Port Moresby, and then only for 18 months. The police welfare officer, a pastor, was assigned to attend the first training in peer education methods which was conducted by an experienced peer education/health promotion expert from Fiji. Following this, criteria were decided upon for the selection of policemen and policewomen to undertake peer education training. By mid-1998, 36 policemen from 14 stations had been trained as peer educators, as well as 16 policewomen from 10 stations, 14 wives of policemen, and 20 security men from firms that employed about 3,900 men. Considerable resistance from the managers of several security forms had to be overcome. Workplace policy workshops were organised with the largest of these firms and one was televised, a ploy that shamed the others and led them also to join in the HIV prevention effort for security men.

Special arrangements were made with the Medical Stores to release condoms to the projects and condom distribution to police stations began almost immediately, and remained in high demand throughout the project. The project delivered cartons of 100 gross boxes of condoms to each precinct in Port Moresby monthly. ${ }^{3}$

The high risk practice of lainap was highlighted both in the peer education training and in a specially developed and tested Pidgin comic book which had

\footnotetext{
3 As this effort could be integrated with other work in the Highlands, the same large cartons were also delivered by one IMR driver to several police stations along the Highlands Highway for a number of years. Post office employees also requested this service and large mail bags full of condoms were silently dropped off at the Goroka, Kainantu and Kundiawa post offices as well. Unfortunately, there were repeated stock-outs of condoms during those years.
} 
a story of Susie, a sex worker caught in the nightly curfews in Port Moresby in those days. When police pulled her into their car and accused her of spreading AIDS, she showed them her negative results from a recent HIV test. That prompted the police to take her into their station and call on other policemen to join them in gang raping her (also known as lainap, 'single file', 'fuck 'n dump', and 'hit 'n run') until morning, when they tossed her out of the station in sad shape. The story then shows them receiving AIDS education as a group from a peer educator and many of the men realise they should be tested. In the doctor's office, one after the other receives positive results until finally the doctor asks one man why so many police were detected positive at one time. The policeman admits that a large number of them had sex with one woman but, he claims, she had a test result showing she was negative. The doctor then explains that that could have been true but they exposed themselves to the semen of the men before them in the lainap and could have been infected in that way. The policeman-patient begins to worry and tells the doctor that his wife is pregnant. The comic book ends up with a set of questions: Could this be you? Do you want more information? And then a set of phone numbers and addresses of a few places to reach for further help. The comic book proved to be very popular and very useful in educating the men about the practice. ${ }^{4}$

\section{Results}

The results are presented for policemen using data from the pre- and first post-test surveys. Results reported for policewomen derive from the baseline surveys only. Many questions were asked about knowledge of HIV and sexually transmitted diseases (STDs), but only those results pertinent to sexual behaviours are reported here.

The pre-test survey included 130 policemen at 19 sites (police stations, residential barracks, training colleges) interviewed in September-November 1996 and the first post-test survey consisted of 197 policemen interviewed in May-June 1997. The policemen sampled represented 18 percent high-ranking officers, 14 percent middle ranks, 62 percent constables and 6 percent auxiliary/ civilian police. They ranged from less than one year to 37 years on the job, with a mean of 9.2 overall. Their ages ranged from 19 to 51 years of age, with the majority between 25 and 34 and an overall average of 31 and they had between none and 13 years of education (overall mean 9.4). Marital status included 73 percent married, and 24 percent single, with a few percent separated/divorced or remarried. Demographic differences between the samples were not significant except for about 10 percent more single men in the second survey.

4 Editors note: see McLeod and Macintyre for later comment on 'Susie's story' 
In the first survey, 33 (25 percent) men reported having had sex with 57 sex workers or rot meri (9 gave gifts but none reported having paid with cash) during the past week that included 76 events of penetrative sex, 51 percent of which had been unprotected. In addition, 84 (65 percent) men reported having sex with 85 non-sex working women (wives and more regular girlfriends) during the past week, which included 229 events of penetrative sex, 90 percent of which had been unprotected. Ten percent of men had joined at least one lainap in the past week, with an average of 3.6 men per lainap (range $=2-5$ ). Following the first nine months of active intervention, in the post-test survey, 35 (18 percent) men reported having sex with 45 sex workers, including 77 events of penetrative sex, 30 percent of which had been unprotected. This time, more men reported paying the women (nine men spent K149 in cash for 14 women and 24 gave gifts (15 gave gifts only and nine both cash and gifts). In addition 123 (63 percent) men reported having sex with 134 non-sex working women, including 310 events of penetrative sex, 88 percent of which was unprotected. This time, 4.6 percent admitted joining lainaps the previous week with an average of 4.2 men per lainap.

Among the 154 security men surveyed, 55 (36 percent) reported having had sex with 79 sex workers or rot meri the previous week. These included 150 sex acts, 76 percent of which were unprotected. Unlike the policemen in 1996, 21 (38 percent) of the security men reported paying the women an average of 6 Kina each, while seven (13 percent) gave gifts. In addition 65 security men (42 percent) reported having sex with 88 non-sex working women (wives and regular girlfriends) a total of 246 times the previous week. Of these sex acts, 98 percent were unprotected. Further, 11 percent of the total sample reported being in a lainap the previous week, with an average of 5.3 men per lainap.

Among the 53 policewomen surveyed, while 86.8 percent said they had steady sex partners (including husbands as 45.3 percent were currently married), 30.2 percent had casual sex in the past week. Of the sample of 53 policewomen, 40 (75 percent) reported having sex with their main partner 105 times over last week, 96 percent of which had been unprotected. In addition, 15 policewomen (28 percent) reported having had casual sex 28 times during the past week, 75 percent of which was unprotected. Only 7.6 percent of these women considered themselves to be at high risk of getting HIV.

\section{Comparing Key Results}

Among policemen, the proportion seeking sex with rot meri (women of the streets) had increased between baseline and the second post-survey from 25 percent to 48 percent and for security men from 36 percent to 54 percent. Condom 
use, however, had risen, particularly with commercial and casual partners from 49 percent of sexual acts to 66 percent $(\mathrm{p}=.01)$ among policemen and from 24 percent to 53 percent among security men $(\mathrm{p}=.004)$. Among policemen, condom use rose from 10 percent to 13 percent with their regular partners (wives and steady girlfriends), but the difference was not significant. Among security men, condom use rose from 2 percent to 13 percent, a significant change.

When the second post-survey was conducted, one manager unfortunately made the decision to change the time period for the question on lainaps. Instead of maintaining 'the last week', he changed it to 'the last month', making direct comparisons very difficult. In the 1998 survey of policemen, eight percent of men reported involvement in a lainap the previous month. As a month is four times the length of a week, we assume that the proportion of policemen involved in lainaps continued to decrease, from 10 percent in the last week to 4.6 percent, to 2 percent; however, technically these results are inconclusive. No post-test results on lainaps among security men were reported.

\section{Discussion}

During the period of this research intervention, numerous nighttime curfews were set in Port Moresby due to the increasing gang violence. The intervention team was often under threat and a considerable amount of grant money (10 percent of total) was spent on security. Even so, the project car was stolen and destroyed when the driver was accosted at gunpoint and the project was greatly handicapped for months. Ambient violence is often associated with increased violence against women and perhaps that period in Port Moresby illustrates such an example. In addition, shortages of condoms occurred repeatedly as orders were not adequately or promptly submitted.

Nonetheless, the data from the surveys appear to show increased condom use by both security men and police with women they consider dangerous, that is, sex workers, but not with others.

Anecdotally, sex workers reported a decline in sexual harassment by policemen over the period through 1998. In one instance in August 1997, six policemen raped two sex workers during a guesthouse raid. The sex workers were arrested but managed to lodge a claim against the police who raped them. The women were released and all six policemen were jailed, pending trial. Over the years, newspapers report allegations of police rape but follow-up of the outcomes do not seem to be of importance. In 2004, a similar event gained international coverage, as 76 alleged sex workers were arrested at a guest house, now labeled a brothel (see Stewart this volume, Fletcher and Gonapa this volume). Interestingly, 35 alleged male sex workers (probably really clients and others) 
were released, presumably because the police do not think the law against prostitution covers males, while the women, nine of whom were juvenile, were detained, then later released on bail. AIDSTOK (Walker 2004) carried reports that the women were forced to blow up condoms and swallow them while being marched two kilometres to the police station. One woman was forced to swallow four of them. The police taunted the women saying they were responsible for spreading AIDS. If the women couldn't swallow the condoms they had the butt of a rifle smashed into their face. Some, mainly younger women, who were not rounded up as quickly, were raped at the guesthouse. Other reports of lainaps by police began to emerge.

While several individuals in PNG worked to help the women, little support was offered by the various concerned government bodies. Eventually all charges were dropped.

It is difficult to know if the reported reduction of lainaps during the 1996-1998 intervention was real. ${ }^{5}$ As no funding was made available for continued targeted interventions with the police, it is no surprise that rape and harassment of sex workers by police and others continues. Research into the topic has also been dropped. HIV prevention projects in PNG seem no longer to be concerned with reducing violence against sex workers. Police in Port Moresby may simply be carrying out the denigration of sex workers that is desired by the public. If so, their entitlement to abuse these women is likely to continue for a long time to come.

\section{References}

Blankenship, K. and S. Koester. 2002. Criminal law, policing policy, and HIV risk in female street sex workers and injection drug users. Journal of Law, Medicine and Ethics 30: 548-559.

Buchanan, H. R., K. Konare and A. Namokari. 1999. Chance Nao Ia! A situational analysis of STI and HIV in the Solomon Islands. Honiara: Ministry of Health and Medical Services.

Donovan, P. 2002. Rape and HIV/AIDS in Rwanda. The Lancet, Dec 360: S17S18.

Goldberg, M. and Unite 88, INSERM. 2005. Initial Results of the Survey on the Health, Living Conditions and Safety of Women in New Caledonia. INSERM, draft report.

5 The author left the project in mid-1997 and could not maintain oversight of the 1998 surveys. See also McLeod and Macintyre, this volume. 
Bangladesh. 2000. Report on the Second Expanded HIV Surveillance, 1999-2000. Dhaka: Government of Bangladesh/UNAIDS.

Jenkins, C. 1996. The homosexual context of heterosexual practice in Papua New Guinea. In Bisexualities and AIDS. International Perspectives, Social Aspects of AIDS Series, ed. P. Aggleton, 191-206. London: Taylor \& Francis Publishers.

Jenkins, C. 2000. Female Sex Worker HIV Prevention Projects: Lessons Learnt from Papua New Guinea, India and Bangladesh. UNAIDS Case Study. Geneva: UNAIDS. http://data.unaids.org/Publications/IRC-pub05/JC438FemSexWork_en.pdf (accessed 27 April 2010).

Jenkins, C. 2006. Violence and Exposure to HIV among Sex Workers in Phnom Penh. Cambodian Prostitutes Union, Women's Network for Unity and Candice Stainsbury. Cambodia: POLICY Project.

http://www.researchforsexwork.org/downloads/Jenkins-CambodiaFinal.pdf (accessed 27 April 2010).

Pelletier, Y. 2002. Qualitative Study on Domestic and Sexual Violence against Kanak Women in New Caledonia. University of Paris and the Pacific Women's Bureau of the Secretariat of the South Pacific Community.

Phal, Serey. 2002. Survey on Police Human Rights Violations of Sex Workers in Toul Kork. [n.p]: Cambodian Prostitutes Union (CPU) and Cambodian Women's Development Association (CWDA). August/September.

Sanday, P. 1986. Rape and the Silencing of the Feminine. In Rape, eds. S. Tomasdelli and R. Porter. Oxford: Basil Blackwell.

SWP (Sex Workers Project at the Urban Justice Center). 2003. Revolving Door. An Analysis of Street-based Prostitution in New York City. New York: Urban Justice Center.

Smith, C. 2003. Major SA study proves rape and AIDS are linked. Health Systems Trust. http://www.hrw.org/en/node/11626/section/1 (accessed 27 April 2010)

Walker, S. 2004. But the men went free. Sex worker raid in Port Moresby. AIDSTOK, March 17. 